\title{
BIOREMEDIATION OF CHROMIUM (VI) BY A MICROBIAL CONSORTIUM ISOLATED FROM TANNERY EFFLUENTS AND THEIR POTENTIAL INDUSTRIAL APPLICATION
}

\author{
Arghyadeep BHATTACHARJEE ${ }^{1^{*}}$, Rajarshi CHAUDHURI², Priyanshu PANDEY ${ }^{3}$, \\ Arup Kumar MITRA ${ }^{4}$ \\ 1, ${ }^{3}$ Department of Biotechnology, National Institute of Technology Durgapur, West Bengal, India \\ ${ }^{2}$ Department of Biotechnology, Regional Centre for Biotechnology, Faridabad, Haryana, India \\ ${ }^{4}$ Department of Microbiology, St. Xavier's College, Kolkata, West Bengal, India
}

Received 28 October 2020; accepted 28 January 2021

\section{Highlights}

Four distinct isolates obtained from tannery effluents were biochemically characterized.

All the isolates not only reduces chromium from its hexavalent to trivalent form but also accumulates it, with IS1 exhibiting the highest reduction capability.

The isolates showed promising protein, leather, and lipid degradation ability, with IS4 demonstrating the highest efficiency.

$\checkmark$ All the the isolates has been found to produce keratinase but maximal enzyme production was achieved by IS1 at $\mathrm{pH}$ 8 and $40{ }^{\circ} \mathrm{C}$ temperature.

Thus, due to the promising multifaceted activities of IS1 and IS4, they were characterized by 16S rRNA sequencing followed by BLAST analysis where they corresponded to Bacillus cereus F4810/72, and Brevibacillus brevis US575 respectively, with high sequence similarity.

Hence, IS1 and IS4 can be employed in the successful bioremediation of wastes from various sources like tanneries, agricultural industries, and poultries in a cost-effective and environment friendly manner.

\begin{abstract}
West Bengal has several leather industries and as such huge amount of leather are processed every year. The tannery effluents are discharged into the land and open water causing soil and water pollution respectively. Chromium is one of the most toxic inorganic contaminants which is well known for its carcinogenicity. Thus, our study focuses on investigating the bioremediation potential of common microflora isolated from tannery wastewater. In our study, Isolate 1 has the highest ability to reduce chromium $\left(\mathrm{Cr}^{6+}\right)$ as compared to others. Isolate 4 has the highest protease, lipase and leather degradation activities. Isolate 1 shows the maximum keratinase activity making it an effective strain for keratinase production. Also, it has been found that $\mathrm{pH} 8$ and temperature $40{ }^{\circ} \mathrm{C}$ was most suitable for keratinase production. Owing to the multidimensional ability of these two isolates, they were identified by $16 \mathrm{~S}$ rRNA sequencing and it reveals that Isolate 1 and Isolate 4 belong to Bacillus cereus F4810/72 and Brevibacillus brevis F4810/72 respectively. Thus, this study establishes the role and efficiencies of these microorganisms in combatting pollution, particularly in the water bodies in which harmful chemicals leak regularly owing to improper waste management by various industries.
\end{abstract}

Keywords: effluent, groundwater, chromium, tannery, bioremediation, keratinase.

\section{Introduction}

Air-water-land, the three essential components of the environment is being rapidly contaminated gradually owing to rapid urbanization, a massive increase in population density, and developing industrialization (Saranraj \& Sujitha, 2013). This eventually leads to the accumulation of heavy metals (Benazir et al., 2010), especially chromium

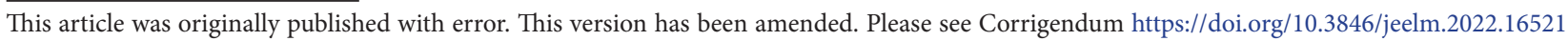

*Corresponding author. E-mail: arghyadeep55@gmail.com 
and lead that poses a significant risk to the health of the society (Igiri et al., 2018). When the toxic contaminants mobilize into the environment, they tend to persist, circulate, and ultimately accumulate in different levels of the food chain destroying the ecological balance (Garg et al., 2012). The Tannery industry is considered to be a major source of pollution and tannery wastewater has become a potential environmental concern nowadays as it contains significant concentrations of toxic inorganic contaminants like chromium, dissolved organic matter, and salts (Sharma \& Malaviya, 2014; Bharagava et al., 2018).

Chromium is one of the most toxic hazardous waste found in tannery effluents (Bharagava et al., 2018). Different anthropogenic activities in tannery industries have led to excessive contamination of Chromium in the soil as well as water bodies and also have increased its bioavailability and bio-mobility as well (Raman et al., 2018). Chromium is a refractory metal that mainly exhibits two inorganic states namely trivalent $\mathrm{Cr}$ (III)) and hexavalent $\mathrm{Cr}$ (VI)). These are considered the most stable oxidation states found in the environment that differ greatly in physical, chemical and biological activities (Sanjay et al., 2020). The hexavalent state of chromium has largely been accepted to be toxic, carcinogenic, and mutagenic due to its high solubility in water, interaction with cellular proteins, and biological membrane permeability (Smith et al., 2002) while trivalent chromium is less water-soluble and less mobile. Plants exposed to environmental chromium cause oxidative metabolic stress (Srinath et al., 2001) that leads to the production of active free radicals. Such active radicals play a crucial role in modulating various signal transduction pathways that ultimately lead to the distortion of cellular membranes and organelles in plants (Oliveira, 2012).

In India, an appreciable concentration of chromium has been found in soil and groundwater samples, especially in the states of Tamil Nadu, Maharashtra, West Bengal places (Kumar \& Riyazuddin, 2010; Gupta et al., 2011). Around $40 \%$ of the 69,000 tons of chromate products used in tanneries have been discharged to water bodies which can cause carcinogenicity upon coming in contact with humans (Iyer et al., 2006). Thus, effective treatment of chromium is an absolute need of the hour in terms of environmental protection management as well as sustainable development. Although treatment of tannery wastewater is carried out by different physicochemical methods like diffusion, reverse osmosis, sedimentation, etc. yet biological treatment of wastewater is much more favorable and cost-effective as compared to others (Mohanty \& Patra, 2011). Bioremediation offers the possibility of using living organisms (bacteria, fungi, algae, or plants), but primarily microorganisms, to degrade or remove environmental contaminants and transform them into nontoxic or lesstoxic forms. It involves different strategies that include biosorption, bioaccumulation, bioreduction, and immobilization of biomaterial(s). Simplistically speaking, microbes employ a variety of biological and chemical processes to reduce chromium at neutral pHs (Garg et al., 2012). Taking all these facts into consideration, our investigation deals with the characterization of the tannery effluents and the ability of microorganisms to biodegrade the components present in the effluent that is responsible for bioremediation. This method will not only be cost-effective but will also be highly efficient along with being environmentally friendly and will require little to low maintenance to keep it operational for a long duration of time.

\section{Materials and methods}

\subsection{Water sample procurement}

Water samples were collected aseptically from the Bantala Leather Complex in the district of South 24 Parganas, West Bengal from $5 \mathrm{~cm}$ below the surface to eradicate contamination from the ground surface and was then subjected to further analysis as detailed below.

\subsection{Physicochemical characterization of the sample}

The physical properties (colour, texture, and odour) of the collected water sample were duly noted. Besides, the $\mathrm{pH}$, as well as the electrical conductivity of the sample, was determined using protocols which have been discussed previously (Jahan et al., 2015). Certain other critical parameters such as the inorganic phosphate (Pi) content, heavy metal (lead and chromium) content, and the total organic carbon content (TOC) of the sample were measured as described elsewhere (De La Luz-Pedro et al., 2019; Jahan et al., 2015; Ates et al., 1997).

\subsection{Isolation and characterization of microbes present in the sample}

The water sample obtained from the tannery was serially diluted to obtain four different dilutions of $10^{-1}, 10^{-2}, 10^{-3}$, and $10^{-4} .0 .1 \mathrm{ml}$ of each of these diluted samples were inoculated separately on freshly-prepared nutrient agar plates, which were then incubated overnight at $37^{\circ} \mathrm{C}$. Four distinct colonies with distinct morphologies were identified in the plate inoculated with the $10^{-4}$ diluted sample. These four colonies were picked up and sub-cultured separately to obtain pure cultures which were named as Isolate 1 (IS1), Isolate 2 (IS2), Isolate 3 (IS3), and Isolate 4 (IS4) respectively. The Gram characteristics and the Motility test of these four isolates were individually determined using standardized protocols as described elsewhere (Trivedi et al., 2015; Adler \& Dahl, 1967). Further, catalase and oxidase tests were also performed as outlined previously (Reiner, 2010; Shields \& Cathcart, 2010). Finally, the isolates showing promising activity in terms of chromium reduction, leather and protein degradation, and keratinase production were identified using $16 \mathrm{~S}$ rRNA sequencing, the details of which have been provided in section 1.9.

\subsection{Chromium reduction assay}

DPC or Diphenylcarbazide assay was used to determine the chromium reduction ability of the four isolates as mentioned previously (Leung et al., 2018). This assay 
estimates the reduction of hexavalent Chromium $\left(\mathrm{Cr}^{6+}\right)$ to trivalent chromium $\left(\mathrm{Cr}^{3+}\right)$ which is indicated by a colour change in presence of the indicator DPC. For the assay, the chromate solution was prepared in nutrient broth at different concentrations of $\mathrm{K}_{2} \mathrm{Cr}_{2} \mathrm{O}_{7}$ viz. $0.01 \mathrm{ppm}, 0.1 \mathrm{ppm}$, $1 \mathrm{ppm}, 10 \mathrm{ppm}$, and $100 \mathrm{ppm}$. The pHs of all these solutions was adjusted to 1 by the addition of $2 \mathrm{M}$ concentrated sulphuric acid followed by the addition of 2 drops of DPC. This immediately resulted in a colour change that showed different intensities of the colour at different concentrations of Chromium as confirmed by absorbance measurement at $590 \mathrm{~nm}$ (Elangovan et al., 2010). A standard curve was plotted accordingly taking the log of the chromium concentration along with their respective absorbance or O.D. (optical density) values at $590 \mathrm{~nm}$.

To determine the actual chromium reduction by the isolates, they were first grown for 4 days in nutrient broth containing $50 \mathrm{ppm}$ of chromium (VI). Later, they were centrifuged for 15 minutes at $5000 \mathrm{rpm}$ and the supernatant was collected. The pellets, on the other hand, were resuspended in sterile water followed by another round of centrifugation at $5000 \mathrm{rpm}$ for 15 minutes. The supernatants were collected and adjusted to a pH of 1 after which 2 drops of DPC were added to each of them. The colour change was observed and the absorbance at $590 \mathrm{~nm}$ was spectrophotometrically determined. Utilizing the standard curve, the absorbance values were converted to ppm values and thus, the actual amount of chromium reduction in ppm was calculated.

\subsection{Leather degradation assay}

The weights of the leather pieces $\left(1 \mathrm{~mm}^{3}\right)$ were recorded after drying them in a hot air oven, after which they were sterilized by UV radiation (Pandi et al., 2019; Chatterjee et al., 2017). The four isolates were inoculated in nutrient broth media separately along with 1 piece of dried and sterilized leather. After one week of incubation at $37^{\circ} \mathrm{C}$, the leather pieces were removed from the media, dried, and weighed to determine the weight loss due to degradation by the isolates.

Since leather degradation is facilitated by certain enzymes such as lipase, keratinase, and protease, appropriate assays were done to determine the individual activity of these enzymes.

\subsection{Lipid degradation assay}

A lipid degradation assay was performed to determine the lipase activity of the isolates. Isolates incubated in nutrient broth medium were cultured at $37^{\circ} \mathrm{C}$ for 2 days followed by centrifugation at $5000 \mathrm{rpm}$ for 15 minutes. The supernatants were collected and used as crude enzymes to study the lipid degradation effect. Vanillin was used as the lipid and a $0.08 \mathrm{M}$ solution of it was prepared which was used for all further experiments (Wang et al., 2014). Three setups were prepared. First, the control had $1 \mathrm{ml}$ of $0.08 \mathrm{M}$ vanillin, $1 \mathrm{ml}$ of water, and $0.1 \mathrm{ml}$ of concentrated $\mathrm{H}_{2} \mathrm{SO}_{4}$. Second, the blank had $2 \mathrm{ml}$ of water along with
$0.1 \mathrm{ml}$ of concentrated $\mathrm{H}_{2} \mathrm{SO}_{4}$ and the experimental setups had $1 \mathrm{ml}$ of the crude enzyme from one of the four isolates along with $1 \mathrm{ml}$ of $0.08 \mathrm{M}$ vanillin and $0.1 \mathrm{ml}$ of concentrated $\mathrm{H}_{2} \mathrm{SO}_{4}$. To determine the amount of vanillin or lipid degraded, the optical density of each tube was measured at $490 \mathrm{~nm}$ after a few minutes using a spectrophotometer (Wang et al., 2016).

\subsection{Protein degradation assay}

Two-days old cultures of the isolates incubated at $37^{\circ} \mathrm{C}$ were centrifuged at $5000 \mathrm{rpm}$ for 15 minutes and the supernatant was used as the crude enzyme to test its protein degradation ability. Accordingly, bovine serum albumin (BSA) was used as the substrate. Four experimental sets were prepared - each of them had $1 \mathrm{ml}$ of $1 \mathrm{mg} / \mathrm{ml} \mathrm{BSA}$ along with $1 \mathrm{ml}$ of the crude enzyme of any one of the four isolates. $4 \mathrm{ml}$ of alkaline copper sulphate was added and the reaction was allowed to proceed for 10 minutes. Then, $0.5 \mathrm{ml}$ of Folin-Ciocalteau reagent was added and finally, after 30 minutes, $0.5 \mathrm{ml}$ of $\mathrm{NaOH}$ was added to stop the reaction, followed by absorbance measurement at $660 \mathrm{~nm}$ as per the standardized protocol as described elsewhere (Pescuma et al., 2012; Hess et al., 1978; Waterborg \& Matthews, 1984). $\mathrm{NaOH}$ was added to prevent errors while absorbance measurement due to differential incubation times. Standard setups were also prepared with varying concentrations of BSA which were treated in the same fashion as the experimental sets except $1 \mathrm{ml}$ of sterile water was used instead of crude enzyme. The absorbance values thus obtained were these setups used to plot the standard curve. The amount of BSA degraded by the isolates was derived from this standard curve using their respective absorbance readings. Finally, the amount of BSA degraded was divided by the total reaction time (40 minutes) to calculate the amount of BSA degraded per minute.

\subsection{Keratinase assay and its optimization}

Initially, the keratinase assay involves the preparation of the feather meal which was prepared by cutting chicken feathers into 3-4 $\mathrm{cm}$ pieces and washing them with sterile water. Chloroform-methanol solution in the ration of 1:1 was prepared in which the cut pieces of the feathers were soaked for 2 days followed by soaking in a 4:1:3 chloroform-acetone-methanol mixture for another 2 days to defat them. The solvents were recycled each day, and the feathers were finally washed several times with sterile water to remove solvent traces followed by drying at $60^{\circ} \mathrm{C}$ and grinding to prepare the feather meal as described previously (Savita \& Archana, 2014).

The media for submerged fermentation was prepared by combining $1 \%$ feather meal, $0.05 \% \mathrm{NaCl}, 0.04 \% \mathrm{~K}_{2} \mathrm{HPO}_{4}$, $0.03 \% \mathrm{KH}_{2} \mathrm{PO} 4,0.01 \% \mathrm{MgCl}_{2}$, and $0.01 \%$ yeast extract and adjusted to a $\mathrm{pH}$ of 8 . The isolates were inoculated into this media and incubated for 3 days at $37^{\circ} \mathrm{C}$ under shaking conditions at $180 \mathrm{rpm}$ (Savita \& Archana, 2014). 
This three-day-old culture was centrifuged at $10000 \mathrm{rpm}$ for 10 minutes and the supernatant was collected and used as the crude enzyme in further experiments. $50 \mathrm{mM}$ Tris-HCl buffer of $\mathrm{pH} 8.0$ was used to suspend $5 \mathrm{mg}$ keratin (from the feather meal) which also acted as a substrate for the keratinase assay. $1 \mathrm{ml}$ of this keratin suspension was added to $1 \mathrm{ml}$ of the crude enzyme from one of the four isolates and then incubated at $50{ }^{\circ} \mathrm{C}$ for an hour. $2 \mathrm{ml}$ of $1 \mathrm{M} \mathrm{NaOH}$ was finally added to stop the reactions and the substrate was then removed by filtration. The absorbance of the filtrate at $595 \mathrm{~nm}$ was determined (El-Refai et al., 2005; Jin et al., 2017). Finally, the amount of enzyme causing an increase in the absorbance at $595 \mathrm{~nm}$ by 0.01 of the sample as compared to the control after 1 hour of reaction at $50{ }^{\circ} \mathrm{C}$ was considered as one unit (U) of keratinase activity in accordance with a previous report (Savita \& Archana, 2014).

Lastly, the optimal conditions with respect to $\mathrm{pH}$ and temperature for the keratinase production by the isolates were determined. To establish the optimal $\mathrm{pH}$, the $\mathrm{pH}$ of the fermentation media was varied from 6 to 10 and the keratinase activity was measured after 3 days of incubation as described above. To identify the most effective temperature, the incubation of the isolates in the fermentation media was performed separately at $37^{\circ} \mathrm{C}, 40^{\circ} \mathrm{C}$, or $45^{\circ} \mathrm{C}$.

\subsection{Isolation of genomic DNA from bacteria}

Owing to the multidimensional abilities in context to their high chromium reduction, keratinase, protease, and leather-degrading ability, the isolates 1 and 4 (designated as IS1 and IS4) were identified using $16 \mathrm{~S}$ rRNA sequencing (Woo et al., 2008). For this, the genomic DNA of freshly cultured isolates 1 and 4 were isolated by $\mathrm{CTAB} / \mathrm{NaCl}$ method as described elsewhere (Park, 2007; Ausubel, 1994). Briefly, $1.5 \mathrm{ml}$ of bacterial culture was centrifuged for 5 minutes followed by resuspending the cell pellet in $600 \mu \mathrm{l}$ of TE buffer. After that $30 \mu \mathrm{l}$ and $5 \mu \mathrm{l}$ of $10 \%$ SDS and $20 \mathrm{mg} / \mathrm{ml}$ Proteinase $\mathrm{K}$ were added respectively. After incubating the solution for approximately $1 \mathrm{~h} 30 \mathrm{mins}, 100 \mu \mathrm{l}$ of $5 \mathrm{M}$ $\mathrm{NaCl}$ and $70 \mu \mathrm{l}$ of $\mathrm{CTAB} / \mathrm{NaCl}$ solution were added for the removal of cell wall debris, denatured proteins, polysaccharides, and other undesirable contaminants. The aqueous phase was extracted by adding an equal volume of Phenol, Chloroform, and Isoamyl alcohol in the ratio of 25:24:1. Finally, the chromosomal DNA was precipitated using isopropanol followed by centrifugation at maximum speed for 10 minutes. The DNA pellet was washed with $70 \%$ ethanol and finally was dissolved in $40 \mu \mathrm{l}$ of TE buffer (Mukherjee et al., 2011).

\subsection{Molecular identification of the isolates}

For the molecular identification of our selected isolates (Isolate 1 and Isolate 4), the 16S rRNA gene was amplified via Polymerase Chain reaction (PCR) and sequenced using the primer sets F-73, 5'-AGAGTTTGATCCTGGCTCAG-3', and reverse primer, R-74,
5'-AAGGAGGTGATCCAAGCC-3'. The PCR fragments were further resolved on a $1.5 \%$ agarose gel followed by electrophoresis in $1 \mathrm{X}$ TAE buffer at $100 \mathrm{~V}$ for 40 minutes and were then subsequently visualized after staining with ethidium bromide. Finally, these amplified $16 \mathrm{~S}$ rRNA fragments were purified and sequenced using Sanger sequencing (Chen et al., 2014) and were exported into BLAST (Basic Local Alignment Search Tool) provided by the NCBI (National Centre for Biotechnology Information) for identification of matches using characterized references sequences provided in the database. This provided useful information about the phylogenetic origin of these isolates and provided alignment scores which were then used to determine the identity of these isolates. The obtained DNA sequence was subjected to DNA and Noise editing using the Bioinformatics software Bio Edit version 7.5 (Sanjay et al., 2020). The 16S rRNA partial sequences were multiple aligned using the MUSCLE tool and subsequently, a phylogenetic tree was constructed through Neighbour Joining (NJ) method in Mega 7.0 (Kumari et al., 2016) keeping parameters default and the bootstrap value was kept 1000 to maximize the nodal supports.

\section{Results}

\subsection{Physicochemical parameters of the sample}

The various physicochemical parameters of the wastewater sample collected from the tannery have been listed in Table 1. The colour, texture, and odour of the sample along with some important chemical properties such as $\mathrm{pH}$, electrical conductivity, inorganic phosphate content, heavy metal content (lead and chromium) were measured accordingly.

Table 1. Physicochemical parameters of the sample

\begin{tabular}{|l|l|}
\hline \multicolumn{1}{|c|}{ Parameter } & \multicolumn{1}{c|}{ Observation } \\
\hline Colour & Yellowish-brown \\
\hline Texture & $\begin{array}{l}\text { Coarse with deteriorated } \\
\text { leather particles }\end{array}$ \\
\hline Odour & Extremely foul \\
\hline $\mathrm{pH}$ & $9 \pm 1.2$ \\
\hline Electrical conductivity & $17.66 \mathrm{Siemens}$ \\
\hline Inorganic phosphate $(\mathrm{Pi})$ & $15.7 \mathrm{mg} / \mathrm{L}$ \\
\hline Lead & $0.19 \mathrm{mg} / \mathrm{L}$ \\
\hline Chromium & $9.7 \mathrm{mg} / \mathrm{L}$ \\
\hline Total organic carbon & $1852.2 \mathrm{mg} / \mathrm{L}$ \\
\hline
\end{tabular}

\subsection{Morphological and biochemical characterization of the isolates}

4 distinct colonies with distinct morphological features were selected from the Nutrient agar plates and from the pure cultures. After that, their Gram characterization and biochemical characterization were observed and were summarized (Appendix Table 1A). The selected isolates were designated as IS1 - IS4. 
a)

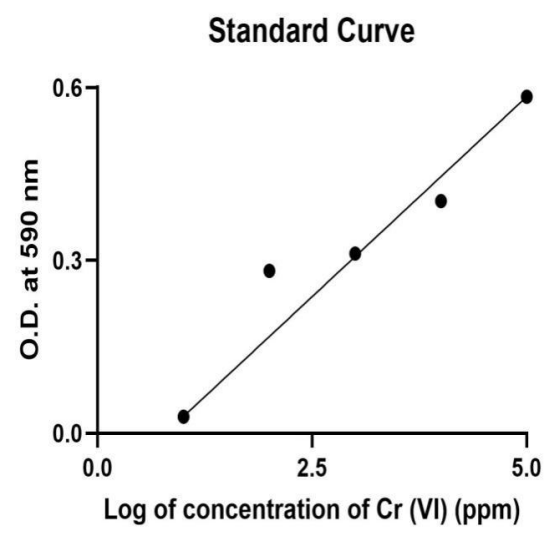

b)

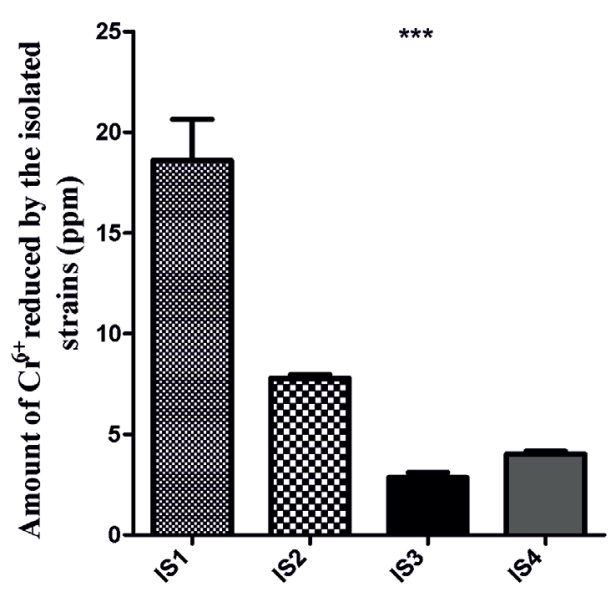

Figure 1. Observation of the amount of Chromium reduced by the isolates: a) Standard curve for determining the amount of Chromium reduced by the isolates by plotting the logarithmic value of Chromium concentrations at X-axis against O.D of the test culture conditions at Y-axis; b) Graphical representation showing the amount of Chromium reduced by the isolates. Y-axis indicates the amount of $\mathrm{Cr}^{6+}$ reduced to $\mathrm{Cr}^{3+}$ in $\mathrm{ppm}$ and the $\mathrm{X}$-axis denotes the test isolates. Data $(\mathrm{n}=3)$ illustrated in the bar diagram as mean \pm SD. ${ }^{* * *} \mathrm{p}<0.0001$ as determined by $\mathrm{t}$-test (IS1 to IS4 represents the isolates)

\subsection{Estimation of the amount of Chromium reduced by the tannery effluent isolated bacteria}

The "Chromium Reductase Assay" is considered as one of the most important bioremediation strategy as it indicates the amount of Chromium reduction $\left(\mathrm{Cr}^{6+}\right.$ to $\left.\mathrm{Cr}^{3+}\right)$ by the microorganisms. 50 ppm Chromium that was present initially in the medium was reduced by the isolated strains as illustrated by graphical representations. Our results show that Isolate 1 (IS1) has the highest $\mathrm{Cr}$ reducing ability as compared to the other strains.

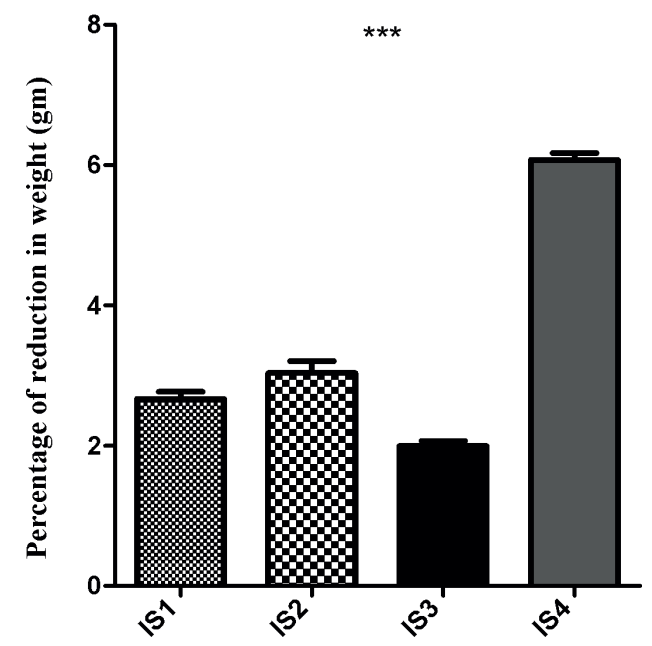

Figure 2. Observation of the amount of leather degraded by the isolates. Graphical representation showing the leather

degrading activity of the isolates. Y-axis indicates the percentage of reduction in weight of the leather in gram (gm) and the $\mathrm{X}$-axis denotes the test isolates. Data $(\mathrm{n}=3)$ illustrated in the bar diagram as mean $\pm \mathrm{SD}$. ${ }^{* *} \mathrm{p}<0.0001$ as determined

by One-way ANOVA (IS1 to IS4 represents the isolates)

\subsection{The Isolates are potent leather degraders}

Our results indicated that Isolate 4 (IS4) has the maximum ability to degrade leather making it a promising as well as an efficient strain for leather degradation.

\subsection{The Isolates have the ability to degrade lipid and protein molecules}

The "Lipase Assay" was performed to evaluate and estimate quantitatively the rate of lipid degradation through the production of industrially important lipase enzyme. Our study indicates that Isolate 4 has the highest lipase activity as estimated by the amount of the degraded substrate per $\mathrm{ml}$ of crude enzyme.

On the other hand, the Protease assay indicates the amount of protein degraded by the microorganisms. Isolate 4 shows the maximum protein degrading ability through the production of commercially important protease enzyme as determined by the amount of protease degraded per minute.

\subsection{Keratinase activity and Optimization of culture conditions for keratinase production}

Keratin plays a pivotal role in providing tensile strength and resistance to the cells. All the strains isolated from tannery effluents were found to produce Keratinase as estimated quantitatively. The strains were grown on a medium supplemented with feathers that act as an important source of carbon and nitrogen. The maximum keratinase activity as shown by Isolate 4 (IS4) was $36 \mathrm{U} / \mathrm{ml}$ at a $\mathrm{pH}$ of 8 . Maximum keratinase production of $52 \mathrm{U} / \mathrm{ml}$ was observed at a temperature of $40{ }^{\circ} \mathrm{C}$ which was considered as an optimum temperature for keratinase production after an incubation period of 4 days. 
a)

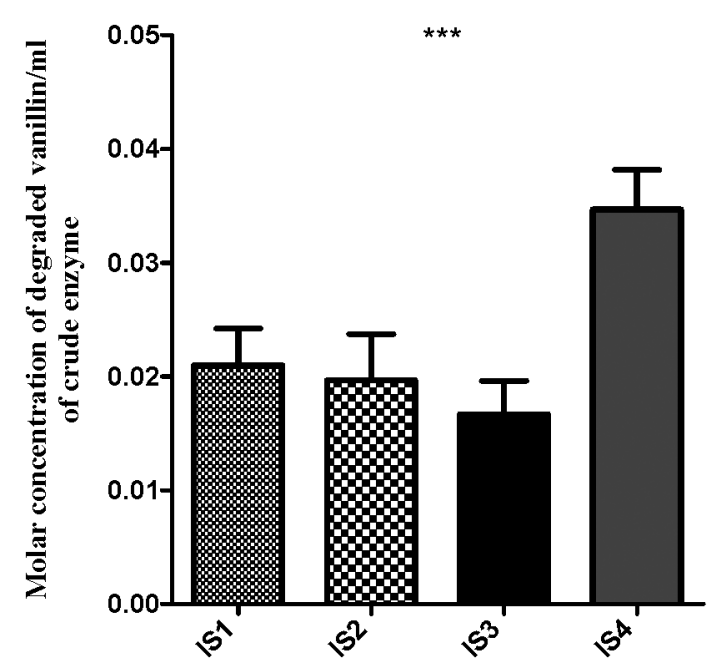

b)

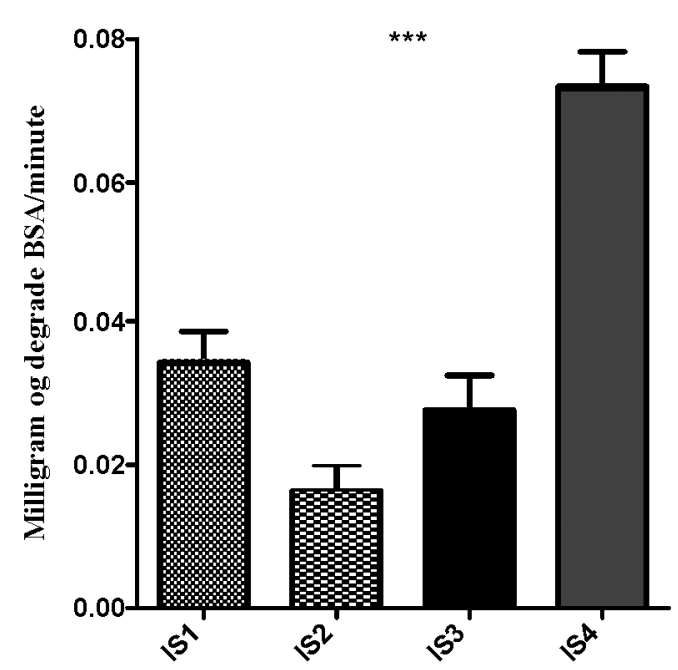

Figure 3. Observation of lipolytic and proteolytic activities of the isolates: a) Graphical representation showing the amount of lipid degraded activity by the microorganisms which was determined by the concentration of the vanillin degraded per ml of the crude enzyme. Y-axis indicates the molar concentration of degraded substrate per $\mathrm{ml}$ of enzyme and the X-axis denotes the test isolates; b) Graphical representation showing the protease activity by the microorganisms which were determined by milligram of degraded BSA per minute. Y-axis indicates the amount of degraded substrate per minute and the X-axis denotes the test isolates. All the data $(\mathrm{n}=3)$ are illustrated in the bar diagram as mean \pm SD. ${ }^{\star * *} \mathrm{p}<0.0001$ as determined by One-way ANOVA

(IS1 to IS4 represents the isolates; BSA: Bovine Serum Albumin)

\subsection{Identification of Isolate 1 (IS1) and Isolate 4 (IS4) through 16s rRNA}

Analysis followed by sequencing of the PCR amplicon of $16 \mathrm{~s}$ rRNA and its alignment in BLAST programme showed that Isolate 1 was Bacillus cereus F4810/72 and Isolate 4 was found to be Brevibacillus brevis US575 and IS1 and IS4 showed $96.5 \%$ and $98 \%$ similarity in sequence alignment respectively.

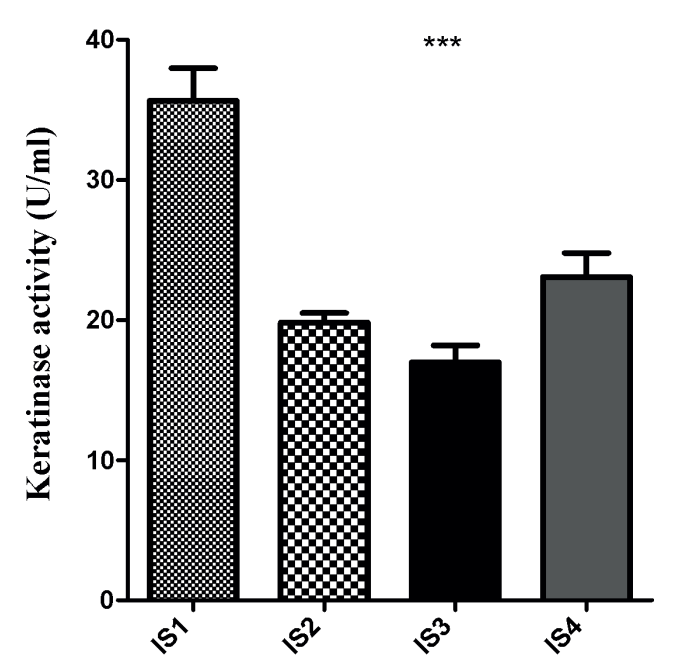

Figure 4. Observation of Keratinase activity of the isolates. Graphical representation showing the amount of keratinase activity by the microorganisms. Y-axis indicates the enzymatic activity expressed in $\mathrm{U} / \mathrm{ml}$ and $\mathrm{X}$-axis denotes the test isolates.

Data $(\mathrm{n}=3)$ illustrated in the bar diagram as mean $+\mathrm{SD}$.

${ }^{* * *} \mathrm{p}<0.0001$ as determined by One-way ANOVA

(IS1 to IS4 represents the isolates)

\section{Discussion}

Remediation of industrial effluents predominantly those heavily contaminated with toxic metals is essential in terms of environmental protection as well as human health (Al-Musharafi, 2016). Apart from humans, animals and plants are also adversely affected by chromium and other industrial wastes that causes degradation of their cell membranes (Mohanty \& Patra, 2011). Recent

\section{Effect of pH on Keratinase Production}

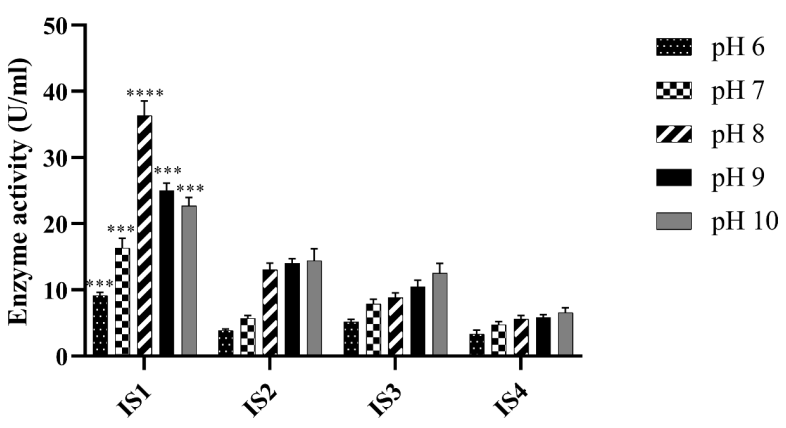

Figure 5. Effect of $\mathrm{pH}$ on the Keratinase activity of the isolates. Graphical representation showing the amount of keratinase activity by the microorganisms at different $\mathrm{pHs}$. $\mathrm{Y}$-axis indicates the enzymatic activity expressed in $\mathrm{U} / \mathrm{ml}$ and $\mathrm{X}$-axis denotes the test isolates. Data $(\mathrm{n}=3)$ illustrated in the bar diagram as mean $\pm \mathrm{SD}$. ${ }^{* * *} \mathrm{p}<0.0001$ as determined by Two-way ANOVA (IS1 to IS4 represents the isolates).

Though the enzymatic activities of IS1 at different $\mathrm{pHs}$ showed similar statistical significance, the activity at $\mathrm{pH} 8$ was the most significant. Also, the enzymatic activity at $\mathrm{pH} 8$ was the highest. Hence, $\mathrm{pH} 8$ was considered as the optimum $\mathrm{pH}$ for keratinase activity 
Effect of Temperature on Keratinase Production

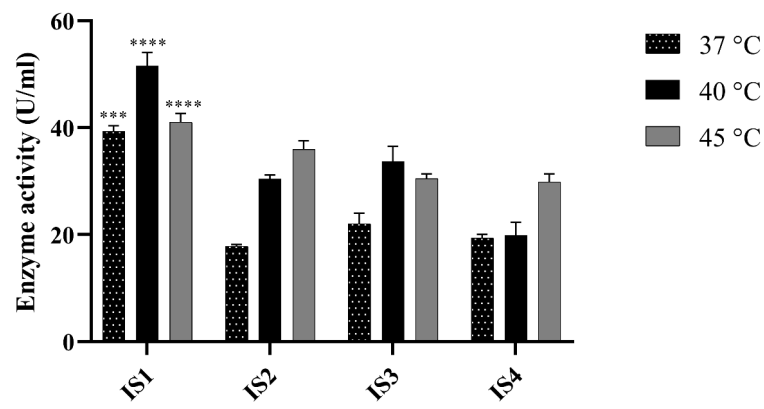

Figure 6. Effect of temperature on the Keratinase activity of the isolates. Graphical representation showing the amount of keratinase activity by the microorganisms at different temperatures. Y-axis indicates the enzymatic activity expressed in $\mathrm{U} / \mathrm{ml}$ and $\mathrm{X}$-axis denotes the test isolates. Data $(\mathrm{n}=3)$ illustrated in the bar diagram as mean $\pm \mathrm{SD}$. ${ }^{* * *} \mathrm{p}<0.0001$ as determined by Two-way ANOVA (IS1 to IS4 represents the isolates). Though the enzymatic activities of IS1 at $40{ }^{\circ} \mathrm{C}$, and 45 have the same statistical significance, the activity at $40^{\circ} \mathrm{C}$ was much higher than that at $45^{\circ} \mathrm{C}$.

Hence, $40{ }^{\circ} \mathrm{C}$ was considered as the optimal temperature for keratinase activity literature has demonstrated the possibility of treatment of such wastes by bioremediation by using various microorganisms like Stenotrophomonas maltophilia (Raman et al., 2018), Bacillus spp., Staphylococcus spp. (Mythili \& Karthikeyan, 2011; Yang et al., 2014), and fungal consortium (Sharma \& Malaviya, 2016). Hence, it becomes clear that the efficient removal of toxic pollutants from the tannery effluents before their discharge to the natural waterways can be accomplished utilizing a sustainable, costeffective, eco-friendly, and easy-to-apply green technology such as bioremediation (Fernández et al., 2018; Vijayaraj et al., 2018). Interestingly, much work has not been done regarding isolation or identification of novel bioremediators from Kolkata, West Bengal except for a few reports (Basu et al., 2014). Also owing to the different biogeochemical scenarios prevailing in different parts of India, the microbes used for bioremediation in areas like Chennai may not be suitable for use in Kolkata due to climatic diversification of these two places. Thus, there is an urgent need for isolation or identification of microbes that can be suitable for bioremediation in an area-specific manner. Accordingly, in this study, an effort was made to isolate

a)

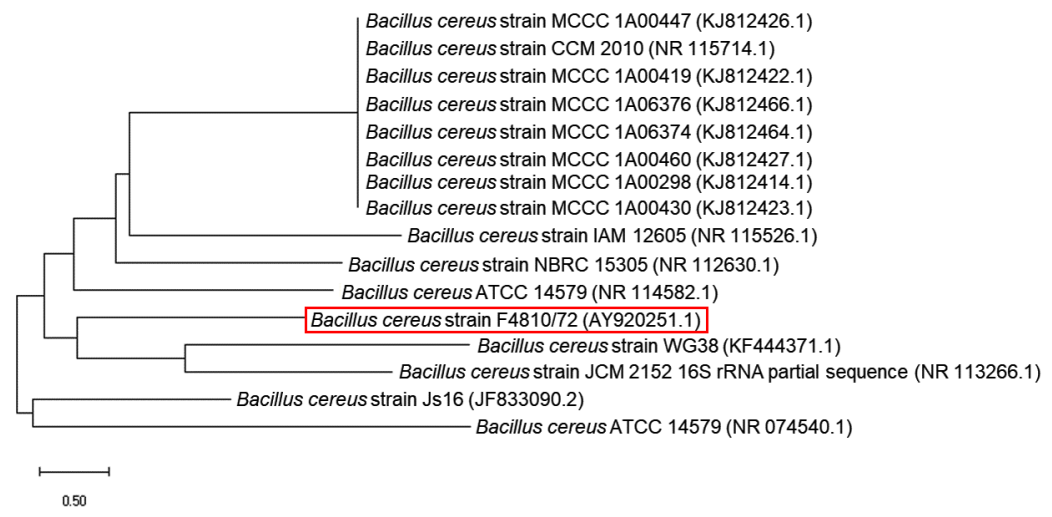

b)

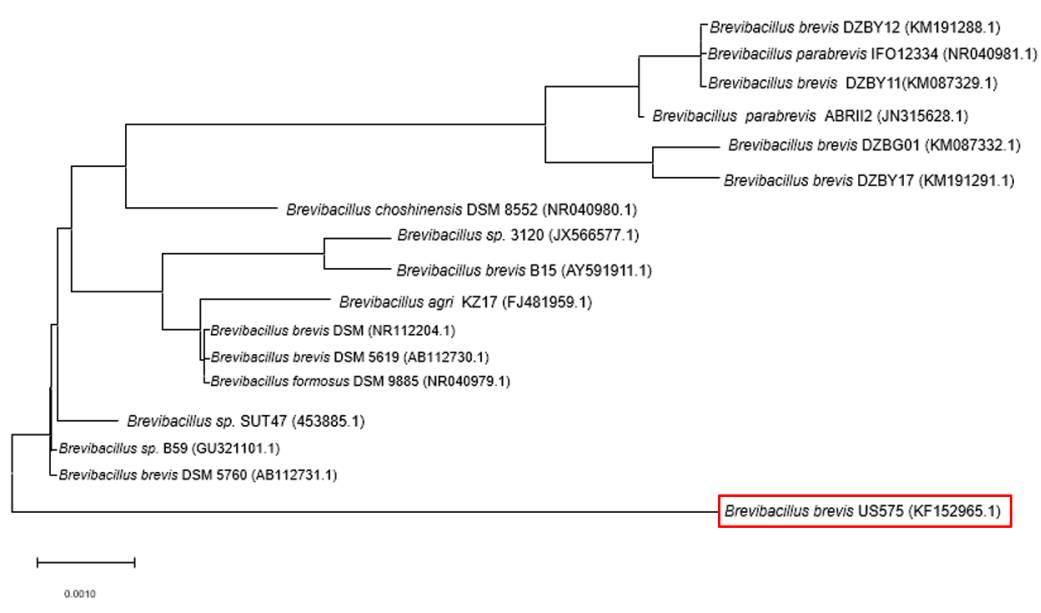

Figure 7. Phylogenetic tree obtained after sequence alignment of (a) Isolate 1, and (b) Isolate 4 by BLAST. A Phylogenetic tree was constructed through Neighbour Joining (NJ) method after aligning the partial sequence of 16S ribosomal RNA gene in Mega 7.0 keeping parameters default and Bootstrap value 1000. The Isolates 1 and 4 were identified as Bacillus cereus F4810/72 and Brevibacillus brevis US575 respectively and they were indicated and highlighted in a red box 
microbes capable of bioremediation of wastes (particularly chromium from tannery effluents) particularly in Kolkata, West Bengal which can then also be employed for waste treatment in other areas with similar climatic conditions.

Thus, in the present study, the effluent collected from the tannery industrial sites was yellowish-brown in colour and had an extremely foul odour. Additionally, deteriorated particles of leather were present. The sample had a high content of inorganic phosphate and heavy metals such as lead and chromium along with a significant concentration of dissolved carbon (Table 1). These indicate a high level of pollutants in the effluent which is released untreated in the environment. Previous characterizations of tannery effluents from other areas have also reported similar observations (Tripathi et al., 2011; Kanimozhi et al., 2013; Jahan et al., 2015). Among the four isolates, IS1, IS2, and IS4 were Gram-positive while IS3 was Gram-negative. All of the isolates showed positive catalase activity while all except IS2 showed negative oxidase activity (Appendix Table 1A).

Numerous reports exist documenting the ability of microbes to reduce chromium (Mythili \& Karthikeyan et al., 2011; Thakur \& Srivastava, 2011). Additionally, microbes isolated from chromium polluted soil has also been shown to reduce chromium (Viti et al., 2003), whereas, heterotrophs and coliforms isolated from tannery effluents were tolerant of heavy metals like mercury and cadmium in addition to reducing chromium (Marzan et al., 2017; Verma et al., 2001). In our study as well, Isolate 1 (IS1) was found to reduce up to $16 \mathrm{ppm}$ of hexavalent chromium which was the highest among the four isolates (Figure 1b). Also, it was found that Isolate 4 (IS4) caused a 5.22\% reduction in the weight of leather after a week (Figure 2), which was highly significant as compared to other isolates. Thus, the isolates have some promising leather degradation ability which is probably due to their natural habitat and this could be one of the reasons of the presence of deteriorated leather particles in the effluent. Indeed, the presence of leather particles has also been reported in tannery effluents from various parts of the world (Hassen \& Woldeamanuale, 2017; Chowdhury et al., 2015; Arias-Barreiro et al., 2010). Isolate 4 (IS4), also had the highest lipase and proteinase activates as demonstrated by the degradation of vanillin and BSA respectively (Figure $3 \mathrm{a}$ and $3 \mathrm{~b}$ ). Earlier reports have also indicated the lipase activity of certain bacteria (Kanimozhi et al., 2013). Thus, our findings establish the promising lipid and protein degrading capability of the Isolate 4 (IS4). Isolate 1 (IS1) had the highest keratin degrading ability (Figure 4). Since the isolates, especially IS1 showed promising keratinase activity, it is evident that physical conditions like temperature and $\mathrm{pH}$ may further enhance this activity. Accordingly, we performed the keratinase experiment under different $\mathrm{pHs}$ and found the maximum activity at $\mathrm{pH} 8$ (Figure 5). This was highly significant in comparison to the keratinase activity of the other isolates. So, pH 8 was concluded as the optimum $\mathrm{pH}$ for keratinase production which also corresponds to previous reports (Jaouadi et al., 2013).
Similarly, different temperature conditions were also tested to elucidate their suitability for keratinase production, and $40{ }^{\circ} \mathrm{C}$ was found as the optimum temperature with the highest keratinase activity being exhibited by Isolate 1 (IS1) (Figure 6). Owing to their promising and multidimensional activities, they were identified using 16S rRNA and were respectively identified as Bacillus cereus F4810/72 and Brevibacillus brevis US575 with high sequence similarity (Figure 7). The high lipase activity shown by B. cereus (IS1) and B. brevis (IS4) coincides with the previous report of a lipase enzyme obtained from Bacillus sp. isolated from tannery wastes (Jaouadi et al., 2013). Thus, in this study two promising candidatesBacillus cereus F4810/72 and Brevibacillus brevis US575 were not only found to reduce chromium but also degrade leather, keratin, proteins and lipids. Earlier reports have shown such properties exist in these bacteria (Zhao et al., 2012) and thus further validate our study. Apart from these, Bacillus subtilis has also been shown to exhibit certain keratinolytic properties (Pillai et al., 2011) with chromium reducing efficiency (Basu et al., 2014). The keratinolytic activity shown by IS4 (B. brevis) was also previously reported particularly concerning chicken feathers which also correlates nicely with our present findings (Jaouadi et al., 2017). Interestingly, previous reports have also mentioned the presence of Bacillus cereus in tannery effluents and have also demonstrated its chromium removal ability which correlates to our findings as well (Kumari et al., 2016). B. cereus could reduce hexavalent chromate by around $70 \%$ which is also in line with our results (Singh et al., 2013). Though fungi, algae, plants, and biomasses have been shown to possess the bioremediation ability of chromium (Mallick \& Rai, 1994; Kapoor \& Viraraghavan, 1995; Romero-Gonzalez et al., 2006; Sharma \& Adholeya, 2011; Vajpayee et al., 2001), it appears that the bacterial world is more proactive in reducing heavy metals like chromium (McLean \& Beveridge, 2001) with greater flexibility and under a variety of environmental conditions. Particularly, the Bacillus genus is well equipped with bioremediation capabilities, especially the reduction of chromium and tolerance to heavy metals like cadmium, and has been found in multiple tannery wastewater samples (Zahoor \& Rehman, 2009; Tripathi et al., 2011). Our investigation reveals that the isolates not only reduce chromium but also accumulate it, thus changing it from cyclical pool to the reservoir pool. It also helps to precipitate chromium at neutral $\mathrm{pH}$ for further removal. The organisms are potent leather degraders. Thus, they can be used in various leather industries for the processing of leather. Also, the keratinolytic property may be useful in recycling keratin-rich agro-industrial and poultry waste byproducts.

Though the treatment of chromium is possible using low-cost adsorbers like activated carbon (Fahim et al., 2006), this approach has two potential downsides. Firstly, the tetravalent chromate can only be neutralized and not the hexavalent form which is the major pollutant in the effluents. Second, the activated carbon needs to be replenished to keep the system functioning. Though they can 
treat wastes with good efficiency, other methods such as activated sludge, sawdust, or electrocoagulation (Sumathi et al., 2005; Verma et al., 1995; Espinoza-Quiñones et al., 2009), are not cost-effective as they often require additional inputs in terms of energy or regular maintenance. Thus, the most suitable process for treating such wastes appears to be bioremediation, or neutralization of chromate using microorganisms, which can function by biosorption, bioaccumulation, or bioreduction (Garg et al., 2012). Bioremediation of chromium from tannery waste becomes a lucrative option as it has negligible upkeep costs along with high efficacy and non-existent environmental damage. $B$. cereus is particularly promising because it has been found in tannery effluents from many areas (Kapoor \& Viraraghavan, 1995) suggesting that it can operate successfully in a variety of environmental conditions and climate and treat wastes from tanneries by not only reducing chromium but also by degrading the leather bits in the wastewater along with degradation of keratins and lipids which may be resent in the waste discharge.

However, further optimizations might be required and further studies will need to be carried out to elucidate the effects of these bacteria on actual tannery effluentswhether they are efficiently able to reduce the chromium to acceptable levels and thereby lower the health hazards related to the discharge of the tannery effluents. Also, as the bacteria were isolated from tannery effluents, it may be said that are well-adapted to survive in the harsh niche provided by the tannery wastewater (containing various heavy metals and numerous pollutants) and hence, will most likely be able to reduce the chromium present in it. The study thus proposes a novel bioremediation strategy along with paving the way for further research with regards to optimization and efficiency studies on treating tannery wastes. We are hopeful that our findings will be utilized in the bioremediation of tannery effluents which will ultimately reduce health hazards such as cancer and help to reduce risk to society.

\section{Conclusions}

Overall, our study concludes that Bioremediation can be a cost-effective procedure if one organism can be used for tackling different pollution problems, in this case, Bacillus cereus F4810/72, Brevibacillus brevis US575 appears to be multidimensional organisms as it not only reduces but also bioaccumulates $\mathrm{Cr}^{6+}$ and at the same times producing enzymes like Protease, Lipase \& Keratinase. Therefore, future research in this regard should expand the knowledge currently obtained through highlighting the activities of chromium tolerant strains in tannery effluents that may pave the way for a pollution-free clean environment in the nearby days.

\section{Acknowledgements}

The authors express their deep gratitude of thanks to Rev. Dr. Dominic Savio, S. J., Principal and Rector, St. Xavier's
College, Kolkata for his constant support throughout the entire project. The authors are deeply indebted to all the professors and laboratory personnel of the Department of Microbiology, St. Xavier's College Kolkata. We are also grateful to the Bantala leather Complex authority for allowing us to collect samples. Financial support from the department is acknowledged.

\section{Funding}

This work is not funded by any funding agency.

\section{Conflicts of interest}

The authors declare that they have no conflict of interest.

\section{Authors contributions}

All authors contributed to the study conception and design. Material preparation, data collection, and analysis were performed by Arghyadeep Bhattacharjee, Rajarshi Chaudhuri, and Arup Kumar Mitra. The first draft of the manuscript was written by Arghyadeep Bhattacharjee and all authors commented on previous versions of the manuscript. All authors read and approved the final manuscript. Conceptualization: Arghyadeep Bhattacharjee, Arup Kumar Mitra; Methodology: Arghyadeep Bhattacharjee, Priyanshu Pandey; Formal analysis and investigation: Rajarshi Chaudhuri, Arup Kumar Mitra; Writing - original draft preparation: Arghyadeep Bhattacharjee; Writing - review and editing: Arghyadeep Bhattacharjee, Rajarshi Chaudhuri, Priyanshu Pandey; Resources: Arghyadeep Bhattacharjee, Rajarshi Chaudhuri, Arup Kumar Mitra; Supervision: Arup Kumar Mitra.

\section{References}

Adler, J., \& Dahl, M. M. (1967). A method for measuring the motility of bacteria and for comparing random and nonrandom motility. Journal of General Microbiology, 46(2), 161-173. https://doi.org/10.1099/00221287-46-2-161

Al-Musharafi, S. K. (2016). Heavy metals in sewage treated effluents: Pollution and microbial bioremediation from arid regions. The Open Biotechnology Journal, 10(1), 352-362. https://doi.org/10.2174/1874070701610010352

Arias-Barreiro, C. R., Nishizaki, H., Okubo, K., Aoyama, I., \& Mori, I. C. (2010). Ecotoxicological characterization of tannery wastewater in Dhaka, Bangladesh. Journal of Environmental Biology, 31(4), 471-475.

Ates, E., Orhon, D., \& Tünay, O. (1997). Characterization of tannery wastewaters for pretreatment - Selected case studies. Water Science and Technology, 36(2-3), 217-223. https://doi.org/10.2166/wst.1997.0522

Ausubel, F. M. (1994). Preparation of genomic DNA from bacteria. Current Protocols in Molecular Biology, 2-4.

Basu, S., Dasgupta, M., \& Chakraborty, B. (2014). Removal of chromium (VI) by Bacillus subtilis isolated from East Calcutta wetlands, West Bengal, India. International Journal of Bioscience, Biochemistry and Bioinformatics, 4(1), 7-10. https://doi.org/10.7763/IJBBB.2014.V4.300 
Benazir, J. F., Suganthi, R., Rajvel, D., Pooja, M. P., \& Mathithumilan, B. (2010). Bioremediation of chromium in tannery effluent by microbial consortia. African Journal of Biotechnology, 9(21), 3140-3143.

Bharagava, R. N., Saxena, G., Mulla, S. I., \& Patel, D. K. (2018). Characterization and identification of recalcitrant organic pollutants (ROPs) in tannery wastewater and its phytotoxicity evaluation for environmental safety. Archives of Environmental Contamination and Toxicology, 75(2), 259-272. https://doi.org/10.1007/s00244-017-0490-x

Chatterjee, A., Bhattacharjee, A., \& Mitra, A. K (2017). A study on the bioremediation ability of the common microflora isolated from tannery effluents. IOSR Journal of Environmental Science, Toxicology \& Food Technology, 11(3), 104-114. https://doi.org/10.9790/2402-110303104114

Chen, L., Cai, Y., Zhou, G., Shi, X., Su, J., Chen, G., \& Lin, K. (2014). Rapid Sanger sequencing of the 16S rRNA gene for identification of some common pathogens. PLoS ONE, 9(2), e88886. https://doi.org/10.1371/journal.pone.0088886

Chowdhury, M., Mostafa, M. G., Biswas, T. K., Mandal, A., \& Saha, A. K. (2015). Characterization of the effluents from leather processing industries. Environmental Processes, 2(1), 173-187. https://doi.org/10.1007/s40710-015-0065-7

De La Luz-Pedro, A., Martínez Prior, E. F., López-Araiza, M. H., Jaime-Ferrer, S., Estrada-Monje, A., \& Bañuelos, J. A. (2019). Pollutant removal from wastewater at different stages of the tanning process by electrocoagulation. Journal of Chemistry, 2019, 8162931. https://doi.org/10.1155/2019/8162931

Elangovan, R., Philip, L., \& Chandraraj, K. (2010). Hexavalent chromium reduction by free and immobilized cell-free extract of Arthrobacter rhombi-RE. Applied Biochemistry and Biotechnology, 160, 81-97. https://doi.org/10.1007/s12010-008-8515-6

El-Refai, H. A., AbdelNaby, M. A., Gaballa, A., El-Araby, M. H., \& Fattah, A. A. (2005). Improvement of the newly isolated Bacillus pumilus FH9 keratinolytic activity. Process Biochemistry, 40(7), 2325-2332. https://doi.org/10.1016/j.procbio.2004.09.006

Espinoza-Quiñones, F. R., Fornari, M. M., Módenes, A. N., Palácio, S. M., da Silva Jr, F. G., Szymanski, N., Kroumov, A. D., \& Trigueros, D. E. (2009). Pollutant removal from tannery effluent by electrocoagulation. Chemical Engineering Journal, 151(1-3), 59-65. https://doi.org/10.1016/j.cej.2009.01.043

Fahim, N. F., Barsoum, B. N., Eid, A. E., \& Khalil, M. S. (2006). Removal of chromium(III) from tannery wastewater using activated carbon from sugar industrial waste. Journal of Hazardous Materials, 136(2), 303-309.

https://doi.org/10.1016/j.jhazmat.2005.12.014

Fernández, P. M., Viñarta, S. C., Bernal, A. R., Cruz, E. L., \& Figueroa, L. I. C. (2018). Bioremediation strategies for chromium removal: Current research, scale-up approach and future perspectives. Chemosphere, 208, 139-148. https://doi.org/10.1016/j.chemosphere.2018.05.166

Garg, S. K., Tripathi, M., \& Srinath, T. (2012). Strategies for chromium bioremediation of tannery effluent. In D. M. Whitacre (Ed.), Reviews of environmental contamination and toxicology: Vol. 217. Reviews of environmental contamination and toxicology (Continuation of residue reviews) (pp. 75-140). Springer. https://doi.org/10.1007/978-1-4614-2329-4_2

Gupta, K., Gaumat, S., \& Mishra, K. (2011). Chromium accumulation in submerged aquatic plants treated with tannery effluent at Kanpur, India. Journal of Environmental Biology, 32(5), 591-597.
Hassen, A. S., \& Woldeamanuale, T. B. (2017). Evaluation and characterization of Tannery Wastewater in each process at batu and modjo tannery, Ethiopia. International Journal of Rural Development, Environment and Health Research, 1(3), $17-26$.

Hess, H. H., Lees, M. B., \& Derr, J. E. (1978). A linear Lowry-Folin assay for both water-soluble and sodium dodecyl sulfatesolubilized proteins. Analytical Biochemistry, 85(1), 295-300. https://doi.org/10.1016/0003-2697(78)90304-4

Igiri, B. E., Okoduwa, S. I., Idoko, G. O., Akabuogu, E. P., Adeyi, A. O., \& Ejiogu, I. K. (2018). Toxicity and bioremediation of heavy metals contaminated ecosystem from tannery wastewater: A review. Journal of Toxicology, 2018, 2568038. https://doi.org/10.1155/2018/2568038

Iyer, G. V., Mastorakis, N. E., \& Theologou, A. I. (2006, May 8-10). Assessment of pollution load from unsafe chromium leather tanneries in India. In Proceedings of the 2006 IASME/ WSEAS International Conference on Energy \& Environmental Systems (pp. 496-505), Chalkida, Greece.

Jahan, M., Akhtar, N., Khan, N., Roy, C., Islam, R., \& Nurunnabi, M. (2015). Characterization of tannery wastewater and its treatment by aquatic macrophytes and algae. Bangladesh Journal of Scientific and Industrial Research, 49(4), 233-242. https://doi.org/10.3329/bjsir.v49i4.22626

Jaouadi, N. Z., Rekik, H., Badis, A., Trabelsi, S., Belhoul, M., Yahiaoui, A. B., Aicha, H. B., Toumi, A., Bejar, S., \& Jaouadi, B. (2013). Biochemical and molecular characterization of a serine keratinase from Brevibacillus brevis US575 with promising keratin-biodegradation and hide-dehairing activities. PLoS ONE, 8(10), e76722.

https://doi.org/10.1371/journal.pone.0076722

Jaouadi, N. Z., Rekik, H., Badis, A., Trabelsi, S., Belhoul, M., Hila, C. G., Irmani, A., Khemir, H., Toumi, A., Bejar, S., \& Jaouadi, B. (2017). The promising keratin-biodegradation and hide-dehairing activities of the keratinase KERUS from Brevibacillus brevis strain US575. In Advances in Science, Technology \& Innovation. Recent Advances in Environmental Science from the Euro-Mediterranean and Surrounding Regions (pp. 133-135). Springer, Cham.

https://doi.org/10.1007/978-3-319-70548-4_45

Jin, H. S., Park, S. Y., Kim, K., Lee, Y. J., Nam, G. W., Kang, N. J., \& Lee, D. W. (2017). Development of a keratinase activity assay using recombinant chicken feather keratin substrates. PLoS ONE, 12(2), e0172712.

https://doi.org/10.1371/journal.pone.0172712

Kanimozhi, K., Devairrakam, E. W. J., \& Jegadeeshkumar, D. (2013). Decolorization of Leather effluent by lipase producing Bacillus sp. Journal of Academia and Industrial Research, 1(12), 813-815.

Kapoor, A., \& Viraraghavan, T. (1995). Fungal biosorption - an alternative treatment option for heavy metal bearing wastewaters: A review. Bioresource Technology, 53(3), 195-206.

Kumar, A. R., \& Riyazuddin, P. (2010). Chromium speciation in groundwater of a tannery polluted area of Chennai City, India. Environmental Monitoring and Assessment, 160(1-4), 579-591. https://doi.org/10.1007/s10661-008-0720-9

Kumari, V., Yadav, A., Haq, I., Kumar, S., Bharagava, R. N., Singh, S. K., \& Raj, A. (2016). Genotoxicity evaluation of tannery effluent treated with newly isolated hexavalent chromium reducing Bacillus cereus. Journal of Environmental Management, 183, 204-211.

https://doi.org/10.1016/j.jenvman.2016.08.017

Leung, R., Venus, C., Zeng, T., \& Tsopmo, A. (2018). Structurefunction relationships of hydroxyl radical scavenging and 
chromium-VI reducing cysteine-tripeptides derived from rye secalin. Food Chemistry, 254, 165-169.

https://doi.org/10.1016/j.foodchem.2018.01.190

Mallick, N., \& Rai, L. C. (1994). Removal of inorganic ions from wastewaters by immobilized microalgae. World Journal of Microbiology and Biotechnology, 10(4), 439-443.

https://doi.org/10.1007/BF00144469

Marzan, L. W., Hossain, M., Mina, S. A., Akter, Y., \& Chowdhury, A. M. A. (2017). Isolation and biochemical characterization of heavy-metal resistant bacteria from tannery effluent in Chittagong city, Bangladesh: Bioremediation viewpoint. The Egyptian Journal of Aquatic Research, 43(1), 65-74. https://doi.org/10.1016/j.ejar.2016.11.002

McLean, J., \& Beveridge, T. J. (2001). Chromate reduction by a pseudomonad isolated from a site contaminated with chromated copper arsenate. Applied and Environmental Microbiology, 67(3), 1076-1084.

https://doi.org/10.1128/AEM.67.3.1076-1084.2001

Mohanty, M., \& Patra, H. K. (2011). Attenuation of chromium toxicity by bioremediation technology. In D. M. Whitacre (Ed.), Reviews of environmental contamination and toxicology: Vol. 210. Reviews of environmental contamination and toxicology (pp. 1-34). Springer.

https://doi.org/10.1007/978-1-4419-7615-4_1

Mukherjee, K., Tribedi, P., Chowdhury, A., Ray, T., Joardar, A., Giri, S., \& Sil, A. K. (2011). Isolation of a Pseudomonas aeruginosa strain from soil that can degrade polyurethane diol. Biodegradation, 22(2), 377-388.

https://doi.org/10.1007/s10532-010-9409-1

Mythili, K., \& Karthikeyan, B. (2011). Bioremediation of Cr (VI) from Tannery effluent using Bacillus spp and Staphylococcus spp. International Multidisciplinary Research Journal, 1(6), 38-41.

Oliveira, H. (2012). Chromium as an environmental pollutant: Insights on induced plant toxicity. Journal of Botany, 2012, 375843. https://doi.org/10.1155/2012/375843

Pandi, A., Kuppuswami, G. M., Ramudu, K. N., \& Palanivel, S. (2019). A sustainable approach for degradation of leather dyes by a new fungal laccase. Journal of Cleaner Production, 211, 590-597. https://doi.org/10.1016/j.jclepro.2018.11.048

Park, D. (2007). Genomic DNA isolation from different biological materials. In E. Hilario \& J. Mackay (Eds.), Methods in molecular biology: Vol. 353. Protocols for nucleic acid analysis by nonradioactive probes (pp. 3-13). Humana Press. https://doi.org/10.1385/1-59745-229-7:3

Pescuma, M., Hébert, E. M., Bru, E., de Valdez, G. F., \& Mozzi, F. (2012). Diversity in growth and protein degradation by dairy relevant lactic acid bacteria species in reconstituted whey. The Journal of Dairy Research, 79(2), 201-208.

https://doi.org/10.1017/S0022029912000040

Pillai, P., Mandge, S., \& Archana, G. (2011). Statistical optimization of production and tannery applications of a keratinolytic serine protease from Bacillus subtilis P13. Process Biochemistry, 46(5), 1110-1117.

https://doi.org/10.1016/j.procbio.2011.01.030

Raman, N. M., Asokan, S., Sundari, N. S., \& Ramasamy, S. (2018). Bioremediation of chromium(VI) by Stenotrophomonas maltophilia isolated from tannery effluent. International Journal of Environmental Science and Technology, 15(1), 207-216. https://doi.org/10.1007/s13762-017-1378-Z

Reiner, K. (2010). Catalase test protocol. American Society for Microbiology.

Romero-Gonzalez, J., Peralta-Videa, J. R., Rodriguez, E., Delgado, M., \& Gardea-Torresdey, J. L. (2006). Potential of Agave lechuguilla biomass for $\mathrm{Cr}$ (III) removal from aqueous solu- tions: Thermodynamic studies. Bioresource Technology, 97(1), 178-182. https://doi.org/10.1016/j.biortech.2005.01.037

Sanjay, M. S., Sudarsanam, D., Raj, G. A., \& Baskar, K. (2020). Isolation and identification of chromium reducing bacteria from tannery effluent. Journal of King Saud University - Science, 32(1), 265-271. https://doi.org/10.1016/j.jksus.2018.05.001

Saranraj, P., \& Sujitha, D. (2013). Microbial bioremediation of chromium in tannery effluent: A review. International Journal of Microbiological Research, 4(3), 305-320.

Savita, K., \& Archana, P. (2014). Screening of keratinase producers from leather. Journal of Environmental Research and Development, 8(3A), 639.

Sharma, S., \& Adholeya, A. (2011). Detoxification and accumulation of chromium from tannery effluent and spent chrome effluent by Paecilomyces lilacinus fungi. International Biodeterioration \& Biodegradation, 65(2), 309-317. https://doi.org/10.1016/j.ibiod.2010.12.003

Sharma, S., \& Malaviya, P. (2014). Bioremediation of tannery wastewater by chromium resistant fungal isolate Fusarium chlamydosporium SPFS2-g. Current World Environment, 9(3), 721. https://doi.org/10.12944/CWE.9.3.21

Sharma, S., \& Malaviya, P. (2016). Bioremediation of tannery wastewater by chromium resistant novel fungal consortium. Ecological Engineering, 91, 419-425.

https://doi.org/10.1016/j.ecoleng.2016.03.005

Shields, P., \& Cathcart, L. (2010). Oxidase test protocol. Library. In ASM Conference for Undergraduate Educators (pp. 1-5). American Society for Microbiology.

Singh, N., Verma, T., \& Gaur, R. (2013). Detoxification of hexavalent chromium by an indigenous facultative anaerobic Bacillus cereus strain isolated from tannery effluent. African Journal of Biotechnology, 12(10), 1091-1103.

Smith, W. A., Apel, W. A., Petersen, J. N., \& Peyton, B. M. (2002). Effect of carbon and energy source on bacterial chromate reduction. Bioremediation Journal, 6(3), 205-215. https://doi.org/10.1080/10889860290777567

Srinath, T., Khare, S., \& Ramteke, P. W. (2001). Isolation of hexavalent chromium-reducing Cr-tolerant facultative anaerobes from tannery effluent. The Journal of General and Applied Microbiology, 47(6), 307-312.

https://doi.org/10.2323/jgam.47.307

Sumathi, K. M. S., Mahimairaja, S., \& Naidu, R. (2005). Use of low-cost biological wastes and vermiculite for removal of chromium from tannery effluent. Bioresource Technology, 96(3), 309-316. https://doi.org/10.1016/j.biortech.2004.04.015

Thakur, I. S., \& Srivastava, S. (2011). Bioremediation and bioconversion of chromium and pentachlorophenol in tannery effluent by microorganisms. International Journal of Technology, 2(3), 224-233.

Tripathi, M., Vikram, S., Jain, R. K., \& Garg, S. K. (2011). Isolation and growth characteristics of chromium(VI) and pentachlorophenol tolerant bacterial isolate from treated tannery effluent for its possible use in simultaneous bioremediation. Indian Journal of Microbiology, 51(1), 61-69.

https://doi.org/10.1007/s12088-011-0089-2

Trivedi, M., Branton, A., Trivedi, D., Nayak, G., Gangwar, M., \& Jana, S. (2015). Agronomic characteristics, growth analysis, and yield response of biofield treated mustard, cowpea, horse gram, and groundnuts. International Journal of Genetics and Genomics, 6(3), 74-80. https://doi.org/10.11648/j.ijgg.20150306.13

Vajpayee, P., Rai, U. N., Ali, M. B., Tripathi, R. D., Yadav, V., Sinha, S., \& Singh, S. N. (2001). Chromium-induced physiologic changes in Vallisneria spiralis L. and its role in phytoremedia- 
tion of tannery. Bulletin of Environmental Contamination and Toxicology, 67, 246-256. https://doi.org/10.1007/s001280117

Verma, N., Batta, S., \& Rehal, R. (1995). Studies on some cyanobacteria for the selection of bioindicators and bioscavengers of chromium metal ions for industrial waste waters. International Journal of Environmental Studies, 47(3-4), 211-215. https://doi.org/10.1080/00207239508710961

Verma, T., Srinath, T., Gadpayle, R. U., Ramteke, P. W., Hans, R. K., \& Garg, S. K. (2001). Chromate tolerant bacteria isolated from tannery effluent. Bioresource Technology, 78(1), 31-35. https://doi.org/10.1016/S0960-8524(00)00168-1

Vijayaraj, A. S., Mohandass, C., Joshi, D., \& Rajput, N. (2018). Effective bioremediation and toxicity assessment of tannery wastewaters treated with indigenous bacteria. 3 Biotech, $8(10)$, 1-11. https://doi.org/10.1007/s13205-018-1444-3

Viti, C., Pace, A., \& Giovannetti, L. (2003). Characterization of $\mathrm{Cr}(\mathrm{VI})$-resistant bacteria isolated from chromium-contaminated soil by tannery activity. Current Microbiology, 46(1), 0001-0005. https://doi.org/10.1007/s00284-002-3800-Z

Yang, W., Yan, L., Wu, C., Zhao, X., \& Tang, J. (2014). Fungal invasion of epithelial cells. Microbiological Research, 169(11), 803-810. https://doi.org/10.1016/j.micres.2014.02.013

Wang, B., Rezenom, Y. H., Cho, K. C., Tran, J. L., Lee, D. G., Russell, D. H., Gill, J. J., Young, R., \& Chu, K. H. (2014). Cultivation of lipid-producing bacteria with lignocellulosic biomass: Effects of inhibitory compounds of lignocellulosic hydrolysates. Bioresource Technology, 161, 162-170. https://doi.org/10.1016/j.biortech.2014.02.133

Wang, J., Gao, Q., Zhang, H., \& Bao, J. (2016). Inhibitor degradation and lipid accumulation potentials of oleaginous yeast Trichosporon cutaneum using lignocellulose feedstock. Bioresource Technology, 218, 892-901. https://doi.org/10.1016/j.biortech.2016.06.130

Waterborg, J. H., \& Matthews, H. R. (1984). The Lowry method for protein quantitation. In J. M. Walker (Ed.), Methods in molecular biology: Vol. 1. Proteins (pp. 1-3). Springer. https://doi.org/10.1385/0-89603-062-8:1

Woo, P. C. Y., Lau, S. K. P., Teng, J. L. L., Tse, H., \& Yuen, K. Y. (2008). Then and now: Use of 16S rDNA gene sequencing for bacterial identification and discovery of novel bacteria in clinical microbiology laboratories. Clinical Microbiology and Infection, 14(10), 908-934. https://doi.org/10.1111/j.1469-0691.2008.02070.x

Zahoor, A., \& Rehman, A. (2009). Isolation of Cr(VI) reducing bacteria from industrial effluents and their potential use in bioremediation of chromium containing wastewater. Journal of Environmental Sciences, 21(6), 814-820. https://doi.org/10.1016/S1001-0742(08)62346-3

Zhao, C., Yang, Q., Chen, W., \& Teng, B. (2012). Removal of hexavalent chromium in tannery wastewater by Bacillus cereus. Canadian Journal of Microbiology, 58(1), 23-28. https://doi.org/10.1139/w11-096

\section{APPENDIX}

Table 1A. Morphological and biochemical characterization of the isolates

\begin{tabular}{|l|l|l|l|l|}
\hline $\begin{array}{c}\text { Designation of } \\
\text { the Isolates }\end{array}$ & \multicolumn{1}{|c|}{$\begin{array}{c}\text { Gram Characterisation \& } \\
\text { Morphological features }\end{array}$} & \multicolumn{1}{|c|}{ Cataliase Test } & \multicolumn{1}{c|}{ Oxidase Test } \\
\hline Isolate 1 (IS1) & $\begin{array}{l}\text { Gram positive short rods with dull grey } \\
\text { coloured and pale yellow coloured colonies } \\
\text { with rough surface }\end{array}$ & Motile & Positive & Negative \\
\hline Isolate 2 (IS2) & $\begin{array}{l}\text { Gram positive short rods with yellowish, } \\
\text { smooth round colonies }\end{array}$ & Non-motile & Positive & Positive \\
\hline Isolate 3 (IS3) & $\begin{array}{l}\text { Gram negative short rods with whitish, } \\
\text { smooth and irregularly shaped colonies }\end{array}$ & Motile & Positive & Negative \\
\hline Isolate 4 (IS4) & $\begin{array}{l}\text { Gram positive shirt rods with whitish and } \\
\text { grey round colonies. }\end{array}$ & Motile & Positive & Negative \\
\hline
\end{tabular}

